Laughton, N. \& Davies, J. (1957). J. gen. Microbiol. 17, 750-757

\title{
Animal Strains of Group G Streptococci and their Serological Typing
}

\author{
BY NANCY LAUGHTON AND JEAN DAVIES
}

Department of Bacteriology, Medical School, Birmingham

\begin{abstract}
SUMMARY: A brief review of group $G$ streptococci and their typing is given with particular reference to canine strains. Two of the Australian type strains of Simmons \& Keogh (1940) were found to be in the group phase and useless for comparative purposes. Four types Kennett, Maxie, Airedale and R51/755 were clearly defined in addition to the Australian types Harrison and Cuthell by reciprocal absorption tests using slide agglutination. Fifty-four other strains of which 35 were of animal and 19 of human origin were examined for type. Of the 38 strains from animal sources, 33 belonged to one of the two types Kennett or Maxie, strains of which came exclusively from animal sources. Six of the human strains and one of the animal ones were untyped.

Type R 51/755 which had been found previously by Maxted (1949) to possess the M28 antigen owed its type-specificity entirely to this antigen and this was not found to be present in any of the other types.

The substances responsible for type-specificity in types Kennett, Maxie, and Airedale differed from those of types Harrison and Cuthell and like that of type R51/755 appeared to be protein in nature. The type-specific substances of types Airedale and Maxie had exactly the same characters as the M28 antigen in being sensitive to peptic but resistant to tryptic digestion. The protein antigen of type Kennett differed from the other three protein type-specific substances in showing only moderate resistance to tryptic digestion.
\end{abstract}

Streptococci of group $\mathrm{G}$ which share a common group-specific polysaccharide in the Lancefield serological classification were first defined by Hare \& Lancefield (1935) among a collection of $\beta$-haemolytic strains mainly from human sources. Since then numerous workers have isolated strains of this group from normal human throat, nose, vagina and skin, but they have seldom been associated with serious human infection. On the other hand, there is more evidence, particularly of the circumstantial type, that some group $G$ strains are pathogenic to animals, particularly to dogs (Hare \& Fry, 1938a, b; Stableforth, 1938; Minett \& Ellis, 1940; Laughton, 1948; Laughton \& Larin, 1954).

In her studies of 55 strains of 'minute-colony' haemolytic streptococci of human origin, Bliss (1937) found that 5 of them belonged to group G. These were shown to possess a specific type substance which was identical with the type-specific substance which Bliss had found in her commonest type belonging to group F called Hav. She proposed the designation type $I$ in both groups for strains containing this type-specific antigen. Simmons \& Keogh (1940) undertook the serological typing of group $G$ strains of human origin. Of the 78 strains which they examined 70 were of the 'large-colony' type and 8 of the 'minute-colony' type. The typing technique used was slide agglutination with 
cocci which had been subjected to tryptic digestion in order to ensure stable suspensions. The 'large-colony' strains fell into three serological types: 62 belonged to type Cole, 7 to type Auburn, and 1 to type Harrison. Four only of the 8 'minute-colony' strains belonged to a single type which was named Cuthell. These strains were not compared with 'type I' of Bliss.

Maxted (1949) showed that a group G strain J 23 possessed an antigen which was identical with the group A type M28 protein antigen described by Lancefield (1943), in its ability to absorb the corresponding antibody and to stimulate the production of type $\mathbf{M} 28$ antibody. A group C strain D 10 also contained the same antigen, but a further examination of this strain suggested that the M 28 antigen was not the major type-specific antigen of this strain.

The present authors, having a collection of group $\mathbf{G}$ strains from animal sources, decided to compare them with the Australian type strains from human sources to ascertain whether type could be related to source and because typing might be of use in epidemiological investigations of animal infection with group $\mathrm{G}$ streptococci. The strains were also examined for the presence of the M28 antigen to ascertain whether it was of major or minor importance in determining type-specificity. Unfortunately, the original plan of comparing animal and human strains with reference to type became impossible as two of the Australian type strains, which incidentally were lodged with the National Collection of Type Cultures, Colindale. London, N.W. 9, as soon as they arrived in this country, were found to have lost their type-specificity.

The animal strains used comprised a number isolated by one of us some years previously and kept in a dried state; these were of canine origin with the exception of two strains, one of which came from a spontaneously occurring infection in a laboratory ferret and the other from the tonsils of a normal monkey.

The strain Do. 178 (Kennett) which was also used by Laughton \& Larin (1954) was isolated from the lungs of a puppy which died of pneumonia. The strain R51/755 was supplied by Mr W. R. Maxted who had found it to contain the $\mathbf{M} 28$ protein antigen; the strain $\mathbf{J} 23$ was no longer available. The group $\mathbf{A}$ strains Small containing the M28 antigen and Streptococcus pyogenes type 1, which was used to absorb the group A antibody from the serum of Small, were supplied by the NCTC.

\section{METHODS}

Grouping of strains. All the strains used were grouped at least twice by precipitin tests with extracts made by Lancefield's and by Fuller's methods. Some group $\mathrm{G}$ strains gave weak cross-reactions with the sera of other groups, particularly with groups $\mathbf{A}$ and $\mathrm{L}$, and less frequently with groups $\mathbf{B}$ and $\mathrm{C}$. Although the majority of cross-reactions were obtained with the acid extracts some were also seen with formamide extracts. Inter-group cross-precipitation was recorded by Bliss (1937), Maxted (1949), Sharpe (1952) and Perry \& Briggs (1955). In some cases these cross-reactions may be due to the nucleoprotein antigen common to all streptococci and in others, it is due to the chance possession of the same antigen by individual strains of different Lancefield serological groups. 
Typing of strains. The method of typing was by slide agglutination with crude and absorbed sera. In reading the tests a positive result was recorded only when marked and clearly visible naked-eye agglutination appeared within $60 \mathrm{sec}$. of mixing the suspension of test organism and serum, and a control test of the same suspension and saline remained stable.

Suspensions of organisms. Standard suspensions of about 30,000 million cocci $/ \mathrm{ml}$. were used. Trouble was experienced at first through loss of agglutinability when organisms were kept at $4^{\circ}$ for a few days in physiological saline containing $\mathbf{0 . 2} \%(\mathrm{v} / \mathrm{v})$ formalin. After trials with varying methods of preservation such as heating, 1/10,000 thiomersalate, doubling the strength of the formalin preservative or using $0.5 \%(\mathrm{w} / \mathrm{v})$ phenol in physiological saline, the last named was found to provide suspensions which showed the least loss of agglutinability up to a period of a month. Suspensions prepared from the same strains at different times were not always equally agglutinable and therefore had to be checked periodically, and tests were repeated several times for confirmation. Stableforth (1932) mentions this variability of agglutination. A more serious difficulty was to obtain stable suspensions; this trouble was frequent and was even variable with regard to the same strain at different times, but it was invariably overcome by patience and various expedients. When everything else failed the cocci were subjected to tryptic digestion and, for the investigation of the nature of the type-specific substances, to peptic digestion as well by the methods given by Maxted (1949).

Immune sera. The cocci were grown for $24 \mathrm{hr}$. in tryptic digest broth containing $0 \cdot 1 \%(\mathrm{w} / \mathrm{v})$ glucose and washed with physiological saline containing $0.4 \%(v / v)$ formalin and resuspended in saline containing $0.2 \%(v / v)$ formalin at about $3000 \mathrm{million}$ cocci/ml. and inoculated intravenously into rabbits whose blood serum had been previously tested for the presence of normal agglutinins since some rabbits had been found to possess these in low titre. Such rabbits were not used. An initial dose of $0.5 \mathrm{ml}$. of suspension was followed by $1 \mathrm{ml}$. on the 2 nd and 3 rd days when no untoward reaction occurred. Subsequently, three to six 3-day courses with 4 days rest in between were given. Some rabbits were adversely affected by these antigens and the loss of several early in the work showed the need for careful regulation of dosage. Maxted (1949) reported the death of three rabbits during their immunization with the group $\mathbf{G}$ streptococcus strain $\mathbf{J} 23$. Test bleedings were made after three or four courses of immunization to ascertain the titre and quality of the antibodies by precipitin and agglutination tests. Type-specific antibodies normally showed early but when the immunization was prolonged group antibodies, as shown by positive cross-precipitin tests, became prominent. The titres of the crude sera varied from $1 / 800$ to over $1 / 2000$ in slide agglutination tests.

Absorption of sera. The method by which the sera was absorbed was that of Griffith (1926). After centrifugation the sera were Seitz-filtered into bijoux bottles and preserved with $1 / 10,000$ thiomersalate.

The minimum adsorptive dose (MAD) of each strain for each homologous serum was measured by the volume of glucose broth which supported a $24 \mathrm{hr}$. 
growth sufficient to absorb all the agglutinins from $0.05 \mathrm{ml}$. of serum. The volume needed for individual sera varied from 25 to $125 \mathrm{ml}$. After preliminary tests with our own strains, reciprocal absorption tests of the Australian prototype strains and some of our strains which appeared to be different, and the group A strain Small, were carried out. In absorbing the sera a good groupantibody absorbing strain was used when necessary in addition to a heterologous type strain, because organisms in the type-specific phase did not always complete the removal of the group antibody unless unreasonable amounts were used, for example, in one test 4 MAD (minimum adsorptive dose) of Cuthell failed to remove all the group antibody from an Auburn serum. After absorption each serum was tested with all the other strains. In the event of a cross reaction, as happened for example between the Kennett serum absorbed with Auburn, and Maxie suspension, or the Maxie serum absorbed with R51/755, and Airedale suspension, the cross-reacting strain was subsequently used as well as other strains to ensure type-specificity. Suitable diagnostic sera purified to contain the major type-specific antibodies only were thus made and used in the testing of the other 54 strains of group G. When an organism was identified as a particular type it was used to absorb the crude serum of the prototype strain with which it had given a positive reaction, using the corresponding MAD. In the case of a few organisms slightly more than 1 MAD was needed to absorb the prototype agglutinins, in other cases when 1 MAD was used, the prototype strain gave a negative reaction but the absorbing strain still gave a positive reaction but with a reduced titre indicating a difference of sensitivity to agglutination.

\section{RESULTS}

Table 1 is representative of the results obtained when the crude sera of 8 group G prototype strains and the group A strain Small containing the M28 protein antigen were cross tested. The extent to which cross-agglutination between strains is representative of group antibodies is speculative because, in an agglutination test in which the surface antigens are the principle participants, adequate contact of a group polysaccharide which might be deeply placed within the bacterial cell and its corresponding antibody in the serum under test, might not be effected; indeed, according to Lancefield (1941) there is no group agglutination corresponding to the group precipitin reaction and neither can variation in non-type-specific agglutination be correlated with the amount of group-specific carbohydrate antibody in the serum because in some cases a positive result may be due to the reaction of the non-specific protein antigen common to all streptococci with the corresponding antibody, but much depends on the quality of the sera used and whether the organism is in a highly specific state, or de-nuded of its more superficial antigens.

This being so, the information to be gained from Table 1 is mainly in the consideration of the negative or low titre results. These results reflect the quality of the sera with regard to type-specificity and also indicate which types are well protected from group agglutination by their type-specific 
Table 1. Slide-agglutination tests of crude streptococcal grouping sera

$\begin{array}{lccccccccc}\begin{array}{c}\text { Strepto- } \\ \text { coccal }\end{array} & \begin{array}{c}\text { Group A } \\ \text { serum } \\ \text { strain }\end{array} & \begin{array}{c}\text { Small } \\ \text { R51/755 }\end{array} & \text { Auburn } & \text { Cole } & \text { Harrison Cuthell } & \text { Kennett } & \text { Maxie } & \text { Airedale } \\ \text { Small } & +++ & +++ & - & - & - & - & \pm & \pm & - \\ \text { R51/755 } & +++ & +++ & ++ & +++ & ++ & \pm & +++ & + & +++ \\ \text { Auburn } & \pm & +++ & +++ & +++ & +++ & \pm & ++ & + & +++ \\ \text { Cole } & \pm & +++ & +++ & +++ & +++ & \pm & + & \pm & +++ \\ \text { Harrison } & - & + & \pm & \pm & +++ & - & - & - & \pm \\ \text { Cuthell } & - & - & \pm & \pm & \pm & +++ & - & - & \pm \\ \text { Kennett } & \pm & +++ & ++ & ++ & +++ & \pm & +++ & + & +++ \\ \text { Maxie } & \pm & +++ & +++ & +++ & +++ & + & +++ & +++ & ++ \\ \text { Airedale } & \pm & - & \pm & - & - & - & \pm & \pm & +++\end{array}$

Agglutination values:,+++ 1 in 200 or more;,++ 1 in $100 ;+, 1$ in $50 ; \pm$, less than 1 in $50 ;-$, negative reaction.

antigens. Among the group G strains, the serum Cuthell and to a lesser extent the serum Maxie are the most type-specific and the organisms Cuthell, Harrison and Airedale appear to be the best protected by their specific antigens from the group-specific and non-specific agglutinins.

The third point of interest is the high degree of reciprocal cross reaction between the group A strain Small and the group G strain R 51/755 which is not seen in the case of the other group $G$ strains. This finding indicates the presence of the common M28 protein antigen.

\section{Reciprocal absorption tests}

Reciprocal absorption tests between the strains Auburn and Cole with 3 different sera against each showed these two strains to be identical because with one exception, when slightly more was needed, 1 MAD of either strain completed the removal of all the agglutinins in the 12 tests; moreover, 1 MAD of the strain Harrison or strain R51/755, which were good group antibody absorbers, removed all the agglutinins of each of the 6 sera. It was therefore concluded that Auburn and Cole strains were in the group phase and the strain Cole was not used again in the investigation. Furthermore, the results of numerous and repeated absorption tests with strain Auburn and the 6 prototype strains established the identity of the latter as distinct types, but certain minor cross-reactions already mentioned above seemed to indicate the sharing of less significant antigens by strains Kennett and Maxie, and by strains Maxie and Airedale. The sharing of such minor antigens, however, could not be satisfactorily confirmed by repeated reciprocal absorption tests and these slight cross-reactions did not interfere with major type definition which was clear-cut in each case.

\section{Typing of additional strains}

Fifty-four other strains were investigated for type-specificity in the way described above. Table 2 shows the type distribution and host source of these strains. The 3 Cuthell strains obtained from human sources were of the 
'minute-colony' type. All other strains were of the 'large-colony' type. Thirty-five strains were of animal origin and 19 of human origin. The types Kennett and Maxie came exclusively from animal sources and accounted for 31 of the 35 animal strains. Six human and 1 animal strain remained untyped.

Table 2. Typing of 54 group $\mathbf{G}$ streptococcal strains from various sources

\begin{tabular}{|c|c|c|c|c|c|c|c|}
\hline Type ... & Cuthell & Harrison & Airedale & Kennett & Maxie & R51/755 & Untyped \\
\hline No. ... & 3 & 4 & 6 & 17 & 14 & $\mathbf{8}$ & 7 \\
\hline Source... & 3 Human & $\begin{array}{l}3 \text { Human } \\
1 \text { Canine }\end{array}$ & $\begin{array}{l}4 \text { Human } \\
2 \text { Canine }\end{array}$ & $\begin{array}{l}12 \text { Canine } \\
2 \text { Milk } \\
1 \text { Ferret } \\
2 \text { Animal } \\
\text { (? origin) }\end{array}$ & $\begin{array}{l}13 \text { Canine } \\
1 \text { Monkey }\end{array}$ & 3 Human & $\begin{array}{l}6 \text { Human } \\
1 \text { Canine }\end{array}$ \\
\hline
\end{tabular}

\section{Nature of the type-specific substances}

The group G strains, and the type A strain Small as a control, were subjected to tryptic and peptic digestion in order to find out something of the chemical nature of the substances determining their type specificity and their relation to the M28 protein antigen. Lancefield (1943) showed and Maxted (1949) confirmed that the M28 antigen withstands tryptic digestion for $72 \mathrm{hr}$. but is inactivated by peptic digestion. Each group $\mathrm{G}$ strain was digested with each of the two enzymes separately and tests were made at 24,48 and $72 \mathrm{hr}$. The strains Auburn and Cole being in the group phase, were tested against their own crude sera and, as was to be expected, both the tryptic- and peptic-digested cocci reacted to titre on account of the group polysaccharide. The other 6 type strains and the group A strain Small were tested against their homologous sera after removal of their respective group antibodies. The strains Harrison and Cuthell also reacted to titre at $72 \mathrm{hr}$. with both treated suspensions, indicating that their type-specific substances were unlikely to be proteins. On the other hand, the strains Airedale, Maxie, Kennett, R51/755 and Small gave negative reactions after $24 \mathrm{hr}$. digestion with pepsin. With the exception of Kennett, the $\mathbf{7 2} \mathrm{hr}$. tryptic digested suspensions of these organisms reacted to titre with their respective homologous sera. The strain Kennett repeatedly showed a sharp fall in agglutination titre after $24 \mathrm{hr}$. treatment with trypsin and it gave a negative result after $48 \mathrm{hr}$.

These findings showed that the type-specific antigens of strains Maxie and Airedale had the same characters as the M28 antigen in relation to tryptic and peptic digestion, but that that of strain Kennett differed in being only moderately resistant to tryptic digestion. To confirm that these strains did not, in fact, contain the M28 protein as well as their major type-specific antigens, the reciprocal absorption of agglutinin tests among Kennett, Maxie, Airedale, R 51/755 and Small were repeated after the removal of the group antibodies by suitable strains of groups $\mathbf{G}$ and $A$ respectively. The results showed no decrease of titre in either direction among the strains Small and R51/755, and Maxie, Kennett and Airedale, but in sharp distinction there was complete reciprocal absorption between Small and R51/755 based on their common possession of 
the $M 28$ antigen, and this antigen appeared to be the only type-specific antigen of $\mathrm{R51} / 755$ because the type-specific agglutinins of its serum were completely removed by Small. It also completely absorbed the type-specific antibody of the serum Small.

\section{DISCUSSION}

With regard to the nomenclature of types within group G, since the Australian type Cuthell was not compared with type 1 (Hav.) of Bliss (1937) these two strains may or may not have been identical types as apparently according to Simmons \& Keogh (1940) the 'minute-colony' strains of group $\mathbf{G}$ comprise more than one type, our 3 such strains none of which came from animal sources, were type Cuthell.

It is also unfortunate that the Australian type strains Cole and Auburn had lost their type-specificity when received by us. We did attempt to regain this by animal inoculation in mice but without success, although a localized inflammatory reaction was obtained. Had they been in the type-specific state we may well have found that they corresponded with two of our named types. Some of our untyped strains may also have been in the group phase, in fact, one was found to be so. It seems probable that the types Kennett and Maxie are primarily animal parasites, but more strains of both animal and human origin need to be typed to confirm this probability.

Maxted (1949) thought that in the case of the group C strain D 10 the M28 protein antigen it contained was not the major type-specific antigen, but it is so in the case of the group G strain R51/755. We did find slight evidence of the sharing of minor type-specific antigens among some of our types but we were unable to confirm this.

We wish to express our sincere thanks to Drs Simmons and Keogh of Victoria, Australia, to Drs E. Davies and N. M. Larin of the Canine Research Station, Kennett, to Mr W. R. Maxted of the Streptococcal Reference Library, Colindale, London, N.W. 9, to Drs A. W. Stableforth and G. Slavin of the Ministry of Agriculture, Fisheries and Food Veterinary Laboratory, Weybridge, and to other laboratory workers in various parts of England and Wales for supplying strains for this investigation.

\section{REFERENCES}

Bliss, E. A. (1937). Studies upon minute haemolytic Streptococci. J. Bact. 33, 625. Griffith, F. (1926). Types of haemolytic streptococci in Scarlet fever. J. Hyg., Camb. 25, 385.

Hare, T. \& Fry, R. M. (1938a). Preliminary observations of infection in dogs by $\beta$-haemolytic streptococci. Vet. Rec. 50, 213.

HARE, T. \& Fry, R. M. (1938b). Clinical observations on $\beta$-haemolytic infections of dogs. Vet. Rec. 50, 1537.

Hare, R. \& Lancefield, R. A. (1935). The serological differentiation of pathogenic and non-pathogenic strains of haemolytic streptococei from parturient women. J. exp. Med. 61, 335.

LANCEFIELD, R. A. (1941). Specific relationship of cell composition to biological activities of haemolytic streptococci. Harvey Lect. 36, 261.

LANCEFIELD, R. A. (1943). Studies on the antigenic composition of group A haemolytic streptococci. J. exp. Med. 78, 465. 
Laughton, N. (1948). Canine $\beta$-haemolytic streptococci. J. Path. Bact. 60, 471.

Laughton, N. \& LaRiN, N. M. (1954). Interaction of the natural host and the canine hepatitis virus on the infectivity of group G streptococci. Nature, Lond. 173, 84.

MAXted, W. R. (1949). Occurrence of the ' $M$ ' substance of type 28 group A streptococci of Lancefield groups B, C and G. J. gen. Microbiol. 3, 1.

Minetr, F. C. \& Ellis, A. A. B. (1940). Streptococcal infections in dogs. Vet. J. 96, 438.

Perry, K. D. \& Briggs, C. A. E. (1955). A common type antigen in streptococci of groups D and E. J. Path. Bact. 70, 546.

Sharpe, E. M. (1952). Occurrence of a common type antigen in streptococei of groups D and N. J. gen. Microbiol. 7, 192.

Simmons, R. T. \& KeOGH, E. V. (1940). The physiological characters and serological types of haemolytic streptococci of groups B, C and $G$ from human sources. Aust. J. exp. Biol. med. Sci. 18, 151.

Stableforth, A. W. (1932). Studies in Bovine Mastitis. J. comp. Path. 45, 185.

Stableforth, A. W. (1938). Streptococcal infections of animals and their treatment. Vet. Rec. 50, 1203. 